\title{
Yaratıcı Drama Yöntemiyle Verilen Toplumsal Cinsiyet Eğitimi Programının Değerlendirilmesi
}

\author{
Hasan Hüseyin Altınova ${ }^{1}$
}

Ömer Adıgüzel²

\begin{abstract}
$\ddot{O z e t}$
Bu araştırmanın amacı, yaratıcı drama yöntemiyle verilen toplumsal cinsiyet eğitimi programını değerlendirmektir. Araştırmanın çalışma grubu Mamak Belediyesi Toplum Merkezi’nden ve 75. Yıl Çağdaş Kadın Gençlik Vakfı Toplum Merkezi'nden hizmet alan kadınlardır. Araştırma, deneysel desenin öntest-sontest kontrol grup modelinden yararlanılarak yapılmıştır. Araştırmada deney grubuna yaratıcı drama yöntemi uygulanmış, kontrol grubuna hiçbir yöntem uygulanmamıştır. Kadınların toplumsal cinsiyet algılarını belirlemek amacıyla "Toplumsal Cinsiyet Algısı" ölçeği öntest, sontest, ve kalıcılık testi olarak kullanılmıştır. Programın değerlendirilmesi için de "Program Değerlendirme Formu" kullanılmıştır. Elde edilen bulgulardan, yaratıcı drama programının uygulandığı deney grubu ile hiçbir uygulamanın yapılmadığı kontrol grubu arasında Toplumsal Cinsiyet Algısı Ölçeği puanlarının öntest sonuçları bakımından anlamlı derecede farklılık görülmemesine rağmen öğrencilerin sontest sonuçları bakımından deney grubu lehine önemli bir fark olduğu anlaşılmaktadır. Ayrıca deney grubunun toplumsal cinsiyet algılarının kalıcılığını sağlamaya ilişkin puanları, hiçbir şeyin uygulanmadığı kontrol grubuna göre daha yüksek olduğu görülmektedir. Kadınların, program değerlendirme formuna yazdıkları geri bildirimlerden hareketle, yaratıcı drama yöntemi kullanılarak uygulanan program ile geliştikleri belirlenmiştir.
\end{abstract}

Anahtar kelimeler: Toplumsal cinsiyet, kadın, yaratıcı drama

\section{EFFECT OF CREATIVE DRAMA METHOD TO GENDER ROLE CONSCIOUS OF WOMEN}

In this research, the effect of creative drama method on gender role consciousness of women has been examined. The research has been done in modern women and youth foundation 75 'th Year and public center of Mamak municipality. Research Groups comprised of 51 women (16 test groups and 15 control groups in Modern Women Foundation 75 'th public center; 10 test groups and 10 control groups in public center of Mamak municipality). It has been paid attention that test and control groups have shown similar socio-demographic features. In this search, as a data gathering tool, Perception Of Gender Role Scale, and query list which are developed by researcher have been used. The research is an experimental study which pretest/last test model with control groups has been used. "Program of developing conscious of gender role with creative drama method prepared by the researcher has been applied to test group in 12 sessions. Each session has been lasted approximately 180 minutes. There has been no application to control group. Qualitative and quantitative data have been gathered in the research In analyzing quantitative data, Mann-Whitney U Test has been used to see equality between pre-test points of test and control group. Wilcoxon Rang Test has been used to find out differences between pre-test and late-test of test and control group. Qualitative data has been commented by describing by the researcher. According to results gathered from test group and control group, in both public center, it has been observed that creative drama method has increased gender role perceptions of women have changed in a positive direction. As also follow up study with this impact continued as great respect.

Key words: Gender, creative drama, women.

1 Öğr.Gör. Ankara Üniversitesi Sağlık Bilimleri Fakültesi. eposta: altinova2012@gmail.com

2 Doç.Dr. Ankara Üniversitesi Eğitim Bilimleri Fakültesi. eposta: omeradiguzel@gmail.com 


\section{Giriş}

Bütün toplumlarda doğuştan gelen biyolojik farkl1l1klar kültürel olarak yorumlanıp değerlendirilir. Böylece kadınlar ve erkeklerin hangi davranış ve faaliyetleri yapabileceklerine, hangi haklara ve güce kimin ne derece sahip olduğuna veya sahip olması gerektiğine ilişkin toplumsal beklentiler geliştirilir. Toplumsal cinsiyet, kimin neyi, nasıl yapacağını, sınırlarını neye göre çizeceğini ve kime hangi özellik ve değerler atfedileceğini belirler.

Toplumsal cinsiyet kavramının anlamı, Simone de Beauvoir'ın ünlü sözünde anlam kazanmaktadır: "Kadın doğulmaz, kadın olunur.” Bu söz kız bebeklerin içlerinde annelik, yumuşaklık, sevecenlik, hamaratlı, oğlan bebeklerin ise savaşçılık, sertlik, alet edevat tamirine yatkınlık vb. tohumları taşıyarak dünyaya gelmediklerini (Bora, 2012) aksine sonradan var edildiklerini anlatmaktadır. Dolayısıyla toplumsal cinsiyet kadınlar ve erkeklere ilişkin uygun rollerin tamamen toplumsal olarak üretildiğini ifade eden "kültürel inşalar"a işaret etmektedir (Scott, 2007, s.11). Bir başka deyişle, insanlar dişi veya erkek cinsiyeti ile doğarlar ancak yetiştirilirken toplumun cinsiyetlerine özgü beklediği roller çerçevesinde kız veya erkek çocuk olmayı öğrenerek büyürler (Terzioğlu ve Taşkın, 2008, s.63).

Oakley (1985)'e göre "cinsiyet” (sex) biyolojik olarak kadın-erkek ayrımını anlatırken; "toplumsal cinsiyet" (gender) kadınlık ile erkeklik arasında ve toplumsal bakımdan eşitsiz bölünmeyi (Akt, Günay ve Bener, 2011) toplum tarafından dayatılan ve beklenilen, erkeklik ve kadınlıkla ilişkilendirilmiş sosyal ve kültürel normları" içeren (Yılmaz, 2007), erkeklik ve kadınlığın biyolojik temeli üzerine kurulan ve toplumsal bağlama göre değişen bir örüntüyü (Bora, 2010) ifade etmektedir.

Toplumsal cinsiyetin varlı̆ğ kadın ile erkek arasında eşitsizliklerin kaynağını oluşturmaktadır. Kadınlarla erkekler arasında hemen hemen tüm toplumlarda görülen eşitsizliklerin kaynağını; kişisel duygular ve kişiler arası ilişkilerden, ekonomik örgütlenme, yaşanan kültür ve devlet düzenine kadar insan deneyimlerinin bütün düzeylerinde görülen karmaşık ilişkiler ağ 1 içerisine gömülü toplumsal cinsiyet ve kesin biçimde birbirinden ayrılan kadın ve erkek toplumsal cinsiyet rolleri oluşturmaktadır (Connell, 2003). Toplumsal cinsiyet, cinsiyet rolü kavramından etkilenir. Bu da ailenin, içerisine girdiği toplumsal çevrenin ve alınan eğitimin etkisiyle, kız ve erkek çocukların cinsiyetlerine uygun roller kazanmalarına ve toplumsal cinsiyet kimliğini edinmelerine sebep olur.

Toplumsal cinsiyetin oluşmasında toplumsallaşma önemli bir yer tutmaktadır. Toplumsallaşma, bireylerin çevresindekilerle arasındaki etkileşim sonucu kendi kültürlerini öğrendikleri süreç olarak tanımlanabilir. Toplumsallaşma, toplum açısından bir sosyal kontrol süreci ve grup yaşamında düzenlilik sağlama yoludur (Fichter,1994; Yogev, 2006). Kadınlar ve erkekler için hangi davranışların doğru ya da uygun, hangi davranışların yanlış olduğu, kadınlar ve erkeklerin hangi işleri yapabilecekleri gibi konular toplumsallaşma sürecinde ve kültürün içinde öğrenilir (Atauz ve diğ., 1999). Toplumsallaşmaya toplumsal cinsiyet açısından baktığımızda, bu, bir kız çocuğunun içinde yaşadığı toplumun "kadınlık" normlarını benimsemesi ve o toplumdaki diğer bireylerle "bir kadın olarak" iletişim kurabilmesidir (Tanrı̈ver, 2003).

Cinsiyete dayalı ayrımcılığın temelinde cinsiyete dayalı işbölümü yatmaktadır (Alkan, 2005, s.41). Cinsiyete dayalı işbölümü, kadınların ve erkeklerin ne yapması gerektiği ya da neleri yapabileceği hakkında toplumda yaratılmış olan fikirlere dayanarak kadınlara ve erkeklere farklı roller, sorumluluklar ve görevler yüklenmesini ifade etmektedir. Toplum, kız ve erkek çocuklara, kadınlara ve erkeklere onların kişisel tercihleri ya da yeteneklerine göre değil; toplumsal cinsiyet rollerine göre farklı görev ve sorumluluklar atfedebilmektedir (Bhasin, 2003, s.27). Kadınlar için ev ile ilgili işleri yürütme ve çocuk bakımı gibi işler öne çıkarken, erkekler için iş rolleri aile rollerinden daha önemli hale gelmektedir (Powell and Greenhause, 2010, s.1012). Toplumsal cinsiyet ve klişelerine göre erkeğin en önemli rolü ailenin geçimini sağlamak iken, kadının en önemli görevi çocuklarını büyütmek ve aile yaşamının devamlılığını sağlamaktır (Moya, Expósito and Ruiz; 2000, s.825). Buda aile içinde kadının karşılıksız emeğini işaret etmektedir. 
Ailede emek türü, kadınlar için karşılıksız emektir. Savran, (2008, s.11) karşılıksız emek türünü şu özellikleriyle tanıtmaktadır: Karşılıksız emek 'görünmeyen' emektir. Görünmez emek olmasının üç temel nedeni vardır: 1) Doğallaştırılmış emektir. Ev içindeki ilişkilere ve pratiklere kadınların doğalarının bir parçası olarak bakılır ve bu işlere kadınların 'doğal olarak' yatkın oldukları düşünülür. 2) Miktarı belirlenemez. Evde yapılan işlerin belirlenmiş saatleri yoktur. İş zamanı ile dinlenme zamanı iç içedir. 3) Karşılıksızdır. Kadınların ev işlerini yapmak ve aile üyelerinin bakım, sağlık ve refahını sağlamak için harcadıkları emeğin karşılığı yoktur.

Cinsiyetçilik terimi, cinsiyete dayalı ayrımcılık olarak da kullanılmakta olup erkek egemen toplumda kadınlara yönelik olumsuz tutumların sonucunda kadının sosyal, kültürel, politik ve ekonomik alanlarda erkeğe göre düşük konumlarda tutulması olarak tanımlanmaktadır (Yaşın-Dökmen, 2004, s.19). Nilüfer Timisi’ye göre ise cinsiyete dayalı ayrımcılık, en geniş anlamıyla kadın ve erkeğin toplumsal cinsiyetine dayalı olarak geliştirilen kalıpyargıları içermekle birlikte özünde kadın cinsine yönelik ayrımcılığı ifade etmektedir.

Kadın ve erkeklere ilişkin ayrımcılığın, eşitsizliğin ve tutumların oluşmasında kalıp yargılar en önemli unsur olarak karşımıza çıkmaktadır. Kalıp yargıları; algılayışları, toplumsal gruplara ilişkin bilgilerimizi inançlarımızı ve beklentilerimizi içeren bilişsel bir yapı olarak tanımlayabiliriz (Mackie, Hamilton, Susskind, Rosselli, 1996). Dünyadaki birçok toplumda erkekler; güçlü, kendine güvenli, korkusuz, bağımsız, gerçekçi gibi güçlü benlikleri yansıtan ve istenir kalıp yargılarla; kadınlar ise bağımlı, pasif, kararsız, duygusal gibi daha zayıf benlikleri yansıtan kalıp yargılarla tanımlanmaktadır (Sakallı-Uğurlu, 2003).

Cinsiyete dayalı ayrımcılığın anlaşılmasında önemli olan nokta, özel alan ve kamusal alanın bir karşıtlık ve astlık/ üstlük oluşturacak biçimde bölünmesidir (Alkan, 2005, s.23). Özel alan ve kamusal alan arasındaki ayrım, pek çok toplumda erkeklerin daha fazla görünürlüğe sahip siyasi ve ekonomik alanlarda üstlendikleri sorumlulukların aksine, kadınların birincil sorumluluklarının özel alanda ve hane içinde belirlenmesi biçiminde ortaya çıkmaktadır. Erkeklerin özel alandaki sorumlulukları ise daha soyut yani daha az birebir emeğe dayalı işlerden oluşmaktadır (Atauz vd, 1999, s. 4); ancak kamusal alandaki rolü sayesinde erkek; baba, koca, evin reisi olarak karısı dahil tüm aile üyeleri üzerinde otorite sahibidir (Poole, 1993, s.76).

Eğer bir tutum, görüş, düşünce değişebiliyorsa, kadına karşı yargılar ve kadınların kendisi hakkındaki yargılar da zaman içinde değişebilir. Bu değişimi sağlamanın yolu; kadınların eğitimi, güçlenmesi ve toplumsal cinsiyet hakkında bilinç kazanmalarıdır. Bu bilinçi kazanmaın bir yolu kadınların eğitimidir. Kadınlar için yetişkin eğitim programlarında birkaç yenilikçi öğretim yöntemi denenmiştir. Bunlar; şarkılar, benzetim (simülasyon) çalışmaları, oyunlar, rol yapma ve tiyatrodur (Sayılan, 1993). Bunlara ek olarak, yaratıcı drama yönteminin kadınların eğitiminde bir grup çalışması yöntemi olarak kullanılabileceği düşünülmektedir.

Yaratıcı drama ortamı, normal şartlarda fikirlerini ifade etmekten çekinen alt sosyo-ekonomik düzeydeki kadınlar için görüş ve fikirlerini söyleyebilme firsatı yaratır, ayrıca eğitim için güvenli ortam oluşturur.

Kadınlara bazı beceriler, kadınlar için tehdit oluşturmayan, güvenilir, fiziksel ve sosyal ortamlarda kadınlar arasındaki etkileşim içinde daha iyi öğretilmektedir (Stromquist, 2002). Bunun için kadınlarla çalışmak için en uygun yer olarak toplum merkezleri görülmektedir. Toplum merkezlerinin hedef kitlesi, kaynaklara ulaşmada güçlük çeken ve dezavantajlı konumdaki öncelikle kadın, çocuk, genç, özürlü olmak üzere tüm toplum kesimidir (Çamur, 2002).

$\mathrm{Bu}$ çalışmada da toplum merekezlerinden hizmet alan kadınlara yönelik olarak; yaratıcı drama yönteminin, toplumsal cinsiyet rolü bilincini geliştirmede etkili ve grupla çalışmak için uygun bir yöntem olacağ düşünülmüştür. Bu amaçla yaratıcı drama yöntemi kullanılarak toplumsal cinsiyet bilinci geliştirme programı geliştirilmiştir. 


\section{Araştırmanın Amacı}

$\mathrm{Bu}$ araştırmanın amacı, yaratıcı drama yöntemiyle kadınlara verilen toplumsal cinsiyet eğitimi programının değerlendirmektir.

\section{Yöntem}

\section{Araştırma Modeli}

Araştırmada, deneysel modellerden "öntest-sontest kontrol gruplu model” (Karasar, 2000) kullanılmıştır. $\mathrm{Bu}$ desenin, deneysel işlemin bağımlı değişken üzerindeki etkisinin test edilmesiyle ilgili olarak araştırmacıya yüksek bir istatistiksel güç sağlayan, elde edilen bulguların neden sonuç bağlamında yorumlanmasına olanak veren ve davranış bilimlerinde sıklıkla kullanılan güçlü bir desen olduğu söylenebilir (Büyüköztürk, 2001, s. 27).

\section{Çalışma Grubu}

Araştırmanın çalışma grubunu Çağdaş Kadın ve Gençlik Vakfı Toplum Merkezi'den (ÇKGV) ve Mamak Belediyesi Toplum Merkezi'nden (MBTM) hizmet alan kadınlar oluşturmaktadır. Araştırma, ÇKGV'da 16 deney grubunda 15 kontrol grubunda olmak üzere toplam 31 kadın ve MBTM'de 10 deney grubunda ve 10 kontrol grubunda olmak üzere 20 kadınla yürütülmüştür.

Araştırma, kadınların üye oldukları toplum merkezlerinde yapılmıştır. Kadınların hepsi ev kadınıdır. Çocukları, okul ve iş yaşamlarına devam edebilmektedir. Bu nedenle araştırmada grup toplantıları kadınların merkezde olduğu saatler düşünülerek planlanmış ve gerektiğinde toplantı saati ve günlerinde değişikliğe gidilmiştir. Grup toplantıları ÇKGV'da her Salı saat 13.00-16.000 saatleri arasında MBTM'de her Perşembe 10-13 saatleri arasında yapılmıştır.

ÇKGV'da deney grubunda bulunan 16 kadından, 13'ü evlidir. Diğerlerinden birinin eşi ölmüş, diğeri boşanmış ve birisi de bekârdır. Kontrol grubunda bulunan 15 kadından, 10’u evlidir. Diğerlerinden üçü boşanmış ve ikisi bekârdır. MBTM'de deney grubunda bulunan 10 kadından 9'u evli bir eşinden ayrılmıştır. Kontrol grubunda bulunan 10 kadından 8'i evli 2'si boşanmıştır.

ÇKGV'de kadınların yaş aralığına baktığımızda deney grubunda birer kadının 20-25 ile 26-30, ikişer kadının 31-35 ile 36-40 arasında beş kadının 41-45 arasında, iki kadının 51-55 arasında, birer kadınında 41-45, 56-60 ve 61-65 yaş arasında olduğu gözlenmiştir. Kontrol rubunda yaş baktığımızda ikişer kadının 20-25 ile 26-30, üç kadının 31-35 arasında, ikişer kadının 36-40 ile 41-45 arasında birer kadının 46-50 ile 51-55 arasında ve iki kadının 56-60 arasında olduğu gözlenmiştir. Deney ve kontrol grubuna katılan kadınların benzer yaş aralıklarında olduğu gözlenmektedir.

MBTM'de kadınların yaş aralığına baktığımızda deney grubunda iki kadının 26-30, dört kadının 31-35 ile 36-40 arasında dört kadının 41-45 arasında olduğu gözlenmiştir. Kontrol grubunda yaş aralığına baktığımızda üç kadının 26-30, üç kadının 31-35 arasında, ikişer kadının 36-40 ile 41-45 arasında olduğu gözlenmiştir. Deney ve kontrol grubuna katılan kadınların benzer yaş aralıklarında olduğu gözlenmiştir.

ÇKGV'da eğitim durumlarına bakıldığında iki grup arasında yine benzer bir dağılım görülmektedir. Deney grubunda üç kadın ilkokul mezunu, altışar kadın ortaokul ve lise mezunu sadece bir kadın üniversite mezunudur. Kontrol grubunda altı kadın ilkokul mezunu, üç kadın ortaokul ve altı kadın lise mezunudur.

MBTM'de eğitim durumlarına bakıldığında deney grubunda dört kadın ilkokul mezunu, üç kadın ortaokul ve üç kadın lise mezunudur. Kontrol grubunda beş kadın ilkokul mezunu, üç kadın ortaokul ve iki kadın lise mezunudur. 
ÇKGV Toplum merkezi ile MBTM birbirine yakın yerlerdedir. Her iki merkezde de grup üyeleri, alt-orta sosyo ekonomik düzeyde bölgelerde ikamet etmektedirler.

Verilerin analizinde en az sekiz oturuma katılan kadınların bilgileri kullanılmıştır.

\section{İşlem}

Yaratıcı drama uygulamaları bir lider (erkek) tarafindan yürütülmüştür. Deney grubunun altıncı ve yedinci toplantısında bir kadın kendi isteğiyle gruptan ayrılmıştır. Araştırmada grup lideri çalışma başlamadan önce ön test uygulaması yapmıştır. Ön testten sonra deney grubuna "Yaratıcı Drama Yöntemiyle Kadınların Toplumsal Cinsiyet Bilincini Geliştirme Programı” uygulanmış, kontrol grubuna hiçbir uygulama yapılmamıştır. Deney grubunun oturumları ortalama olarak 180 dakika sürmüştür. Uygulamanın bitiminde deney ve kontrol grubuna ölçme araçları tekrar uygulanmış ve cinsiyet rolü algısında anlamlı bir fark olup olmadığına bakılmıştır. Uygulama bitiminden 8 ay sonra ölçek tekrar uygulanarak etkinin uzun süreli olup olmadığına bakılmıştır. Araştırma gruplarına uygulanan işlem Tablo 1'de verilmiştir.

Tablo 1: Araştırmanın Deseni

\begin{tabular}{|l|l|l|l|l|}
\hline Gruplar & Ön test & İşlem & Son test & İzleme \\
\hline Deney & TCA & $\begin{array}{l}\text { 12 oturumdan oluşan } \\
\text { "yaratıcı drama" } \\
\text { uygulaması. }\end{array}$ & $\begin{array}{l}\text { TCA } \\
\text { Programı } \\
\text { değerlendirme } \\
\text { Formu }\end{array}$ & TCA \\
\hline Kontrol & TCA & Yok & TCA & TCA \\
\hline
\end{tabular}

Programın akışı: Yaratıcı drama uygulamasında ilk üç oturum öncelikle grup üyelerinin tanışma, grup etkileşimi, güven ve uyumunu sağlayıcı etkinlikleri içermektedir. Daha sonraki oturumlar ise toplumsal cinsiyet ile ilgili konuları içermiştir. Böylelikle kadınların aşamasal bir gelişim göstermesi amaçlanmıştır.

Oturumlarda kadınların toplumsal cinsiyet rollerini etkileyen faktörleri fark etmeleri amaçlanmıştır. Seçilen konu ve oyunlar ve canlandırmalarda bu durumlar ön plana çıkarılmaya çalışılmıştır.

Uygulanan programın konu başlıkları aşağıda verilmiştir.

1. Oturum: Tanışma, Grupla İletişim-Etkileşim.

2. Oturum: Kendini Tanıma

3. Oturum: İletişim Becerileri

4. Oturum: Kadın Olmak- Erkek Olmak

5. Oturum: Kadın Sorunları ve Sorun Çözme Yaklaşımı

6. Oturum: Toplumsal Cinsiyet

7. Oturum: Toplumsal Rol, Statü, Kalıp yargılar

8. Oturum: Kadın Hakları, Eğitim Çalışma Hayatına Giriş, İş Bölümü

9. Oturum: Kitle İletişim Araçlarında Toplumsal Cinsiyet

10. Oturum: Kamusal Alan- Özel Alan

11. Oturum: Cinsiyetçi Çocuk Yetiştirme

12. Oturum: Genel Değerlendirme ve Bitirme Etkinlikleri 


\section{Veri Toplama Aracı}

Araştırmada veri toplama aracı olarak anket formu kullanılmıştır. Anket formu 3 bölümden oluşmaktadır: Birinci bölümde; cinsiyet, yaş grubu, öğrenim durumu gibi velileri tanıtıcı demografik bilgileri ortaya koymayı amaçlayan sorular bulunmaktadır.

Anket formunun ikinci bölümünde ise velilerin toplumsal cinsiyet algılarını için Altınova ve Duyan'ın (2013) geliştirdiği “Toplumsal Cinsiyet Algısı Ölçeği” kullanılmıştır. Anket Formunun Üçüncü bölümünde “ Programı Değerlendirme Formu” yer almaktadır, bu form son oturumda uygulanmıştır.

Toplumsal Cinsiyet Algısı Ölçeği: Ölçek Altınova ve Duyan (2013) tarafindan geliştirilmiş ve geçerlilik güvenilirlik çalışması yapılmıştır. Özellikle yetişkinlere uygulanabilecek şekilde geliştirilmiş bir ölçektir. Bireylerin değişik alanlara ilişkin toplumsal cinsiyet rollerini nasıl algıladıklarını ile ilgili tutumlarını ölçme özelliğine sahiptir. Ölçek toplam 25 maddeden oluşmaktadır. Her madde için, "kesinlikle katılıyorum”, "katılıyorum", "kararsızım", "katılmıyorum", "kesinlikle katılmıyorum” maddelerinden biri seçilerek 1 ile 5 arasında puanlanmaktadır. Toplam ölçek puanı hesaplanırken bazı maddeler tersten puanlanmaktadır (2., 4., 6., 9., 10., 12., 15., 16.,17.,18., 19., 20., 21., 24. ve 25. maddeler tersten puanlanmıştır). Ölçekten alınabilecek en düşük puan 25 , en yüksek puan 125 'dir. Puanın yüksek olması toplumsal cinsiyet algısının yüksek olduğunu, düşük olması ise toplumsal cinsiyet algısının düşük olduğunu gösterir.

Ölçeğin iç tutarlılığı ile ilgili analizler toplam 443 kişi üzerinde hesaplanmış ve Cronbach Alfa iç tutarlılık katsayısı ,872 olarak hesaplanmıştır.

\section{Programı Değerlendirme Formu}

Programı Değerlendirme Formu, grup oturumlarını değerlendirmek için hazırlanan katılımcılara son oturumda sorulan onbir soruyu içermektedir. Bu sorular aşağıdaki verilmiştir.

\section{Programı Değerlendirme Formu}

1. Grupta bir kadın olarak kendinizle ilgili öğrendiğiniz en önemli şeyler nelerdir?

2. Grup yaşantısı içinde ne tür kararlar verdiniz?

3. Bu gruptan alıp günlük yaşamınızda en çok uygulamak istediğiniz şey ne olabilir.

4. Grupta başka neleri tartışmak isterdiniz?

5. Programın yürütülmesi sırasında görülen aksaklıklar nelerdir?

6. Programa eklenmesi, geliştirilmesi veya çıkarılması gereken konular var mı?

7. Bu çalışmada en çok ilginizi çeken konu ve etkinlikler nelerdi?

8. Benim için bu çalışmaların en olumsuz/zayıf yanı?

9. Benim için bu çalışmaların en olumlu/üstün yanı?

10. Liderin nitelikleri hakkında neler düşünüyorsunuz? (Lider ve liderin tutumunun grup üzerindeki etkisi)

11. Diğer duygu ve düşünceleriniz nelerdir?

\section{Verilerin Analizi}

Verilerin analizinde SPSS 17.00 istatistik paket programı kullanılmıştır. Deney ve kontrol grubuna alınan kadınların Toplumsal Cinsiyet Algısı Ölçeğinden aldıkları puanlar deney ve kontrol grubu, ön ve son ölçümler bakımından karşılaştırılmasında Mann-Whıtney U testinden yararlanılmıştır. Uygulama öncesi ve sonrasında kadınların cinsiyet rolü algısında meydana gelen değişimin karşılaştırılması için Wilcoxon Sıralı İşaretler Testi 
uygulanmıştır. İzleme çalışmasında deney ve kontrol grupları arasındaki kadınların cinsiyet rolü algısı puanlarını karşılaştırmak için Wilcoxon Sıralı İşaretler Testi yapılmıştır. Elde edilen sonuçların yorumlanmasında. 05 anlamlılık düzeyi dikkate alınmıştır.

\section{Bulgular ve Yorum}

$\mathrm{Bu}$ bölümde uyulama öncesi ve sonrasına ilişkin Toplumsal Cinsiyet Algısı Ölçeği ve Program Değerlendirme Formu'ndan elde edilen bulgulara yer verilmiştir.

\section{Toplumsal Cinsiyet Algısı Düzeyi Puanlarına İlişkin İstatiksel Bilgilere İlişkin Bulgular}

ÇKGV ve MBTM'de deney ve kontrol grubunda bulunan kadınların Toplumsal Cinsiyet Ölçeğinden aldıkları öntest, sontest, izleme ve öntest sontest farkının puan ortalaması ve standart sapmaları tablo 2'de verilmiştir.

Tablo 2: Toplumsal Cinsiyet Ölçeğinden Aldıkları Öntest, Sontest, İzleme ve Sontest-Öntest Farkına İlişkin Ortalama, Standart Sapma Sonuçlarl

\begin{tabular}{|c|c|c|c|c|c|c|c|c|c|c|}
\hline \multicolumn{2}{|c|}{} & \multicolumn{2}{c|}{ Öntest } & \multicolumn{2}{c|}{ Sontest } & \multicolumn{2}{c|}{$\begin{array}{c}\text { Sontest-Öntest } \\
\text { Farkı }\end{array}$} & \multicolumn{2}{c|}{ Izleme } \\
\hline \multirow{2}{*}{ Grup } & Yer & $\mathbf{n}$ & $\bar{X}$ & Ss & $\bar{X}$ & Ss & Fark $\bar{X}$ & Ss & $\bar{X}$ & Ss \\
\hline \multirow{2}{*}{ ÇKGV } & Deney & 16 & 93,1 & 19,79 & 105,5 & 13,33 & 12,4 & 6,63 & 105 & 8,15 \\
\cline { 2 - 12 } & Kontrol & 15 & 84,8 & 11,95 & 84,5 & 8,34 & $-0,3$ & 1,23 & 89,8 & 8,81 \\
\hline \multirow{2}{*}{ MBTM } & Deney & 10 & 81,0 & 15,11 & 92,0 & 10,92 & 11 & 8,96 & 95,2 & 6,08 \\
\cline { 2 - 11 }$y$ & Kontrol & 10 & 82,5 & 16,50 & 86,0 & 12,02 & 3,5 & 11,35 & 86,4 & 9,52 \\
\hline
\end{tabular}

Tablo 2'ye bakıldığında grup çalışması öncesinde yaratıcı drama uygulamasına katılmayı kabul eden ÇKGV'deki 16 kadının TCA ölçeğinden aldığ 1 puan ortalaması 93,1 MBTM'deki 10 kadının puan ortalaması 81,0 ve yaratıcı drama uygulamasına katılmayacak olan ÇKGV'daki 15 kadının puan ortalaması 84,8 MBTM'deki 10 kadının puan ortalaması 82,5 olarak hesaplanmıştır.

Tablo 2'e bakıldığında grup çalışması sonrasında yaratıcı drama uygulamasına katılmayı kabul eden ÇKGV'daki 16 kadının TCA Ölçeğinden aldığı puan ortalaması 105,5 MBTM'deki 10 kadının puan ortalaması 92,0 ve yaratıcı drama uygulamasına katılmayacak olan ÇKGV'deki 15 kadının puan ortalaması 92,0 MBTM'deki 10 kadının puan ortalaması 86,0 olarak hesaplanmıştır.

İzleme çalışmasında ÇKGV'daki deney grubundaki 16 kadının TCA Ölçeğinden aldığı puan ortalaması 105, kontrol grundaki 15 kadının aldığı puan 89,8 MBTM'deki deney grubundaki 10 kadının puan ortalaması 95,2, kontrol grubundaki 10 kadının puan ortalaması 86,4 olarak hesaplanmıştır.

Sontest-Öntest puan farkı ÇKVD'deki deney grubunda bulunan kadınlarda 12,4, kontrol grubunda -0,3, MBTM'deki deney grubunda bulunan kadınlarda 11, kontrol grubunda bulunan kadınlarda 3,5 olarak hesaplanmıştır.

Bu sonuçlara göre deney öncesi ÇKGV' da ve MBTM' deki kadınlarda Toplumsal Cinsiyet Ölçeği puan ortalamaların ortalamanın biraz üzerinde olduğu, deney sonrasında ise yükseldiği gözlenmektedir. Deney sonrasında her iki toplum merkezindeki kadınlarda toplumsal cinsiyet algı puanların birbirine yakın düzeyde arttı̆̆1 gözlenmektedir. 
MBTM'de deney ve kontrol grubunda bulunan kadınların toplumsal cinsiyet algısı ölçeğinde aldıkları puanların ortalaması ÇKGV'da bulunan deney ve kontrol grubu kadınlarına göre daha düşük olduğu gözlenmektedir.

\section{Uygulama Öncesi Toplumsal Cinsiyet Algısı Düzeyinin Gruplar Arası Değişimine İlişkin Bulgular}

Deney ve kontrol grubu öntest puanları arasında anlamlı bir fark olup olmadığını belirlemek amacıyla Mann Whitney U testi yapılmış, sonuçlar Tablo 3'te sunulmuştur.

Tablo 3: Deney ve Kontrol Gruplarının Öntest Toplumsal Cinsiyet Algisı Puanlarına İlişkin Ortalama, Standart Sapma ve Mann Whitney U Testi Sonuçları

\begin{tabular}{|c|c|c|c|c|c|c|}
\hline \multirow{2}{*}{ Grup } & Yer & $\mathbf{n}$ & $\bar{X}$ & Ss & $\mathbf{z}$ & $\mathbf{p}$ \\
\hline \multirow{2}{*}{ ÇKGV } & Deney & 16 & 93,1 & 19,79 & \multirow{2}{*}{1,464} & \multirow{2}{*}{, 143} \\
\cline { 2 - 5 } & Kontrol & 15 & 84,8 & 11,95 & & \\
\hline \multirow{2}{*}{ MBTM } & Deney & 10 & 81,0 & 15,11 & \multirow{2}{*}{, 303} & \multirow{2}{*}{, 762} \\
\cline { 2 - 5 } & Kontrol & 10 & 82,5 & 16,50 & & \\
\hline
\end{tabular}

Tablo 3 incelendiğinde deney ve kontrol grubunun Toplumsal Cinsiyet Algııı Ölçeği öntest puanları arasında anlamlı bir farklılık olup olmadığını belirlemek için yapılan Wilcoxon İşaretli Sıralar Testi sonuçlarına göre puanlar arasında anlamlı farklılığın olmadığı $(\mathrm{p}>, 05)$ görülmektedir.

$\mathrm{Bu}$ durumda deney ve kontrol grubunda bulunan kadınların uygulama öncesinde toplumsal cinsiyet algılarının benzer olduğu belirlenmistir. Bir baska ifadeyle deney ve kontrol grubu öğrencilerinin çalısmalara benzer düzeyde basladığı söylenebilir.

\section{Uygulama Sonrası Toplumsal Cinsiyet Algısı Düzeyinin Gruplar Arası Değişimine İlişkin Bulgular}

Deney ve kontrol grubu sontest puanları arasında anlamlı bir fark olup olmadığını belirlemek amacıyla Mann Whitney U testi yapılmış, sonuçlar Tablo 3’te sunulmuştur.

Tablo 4: Deney ve Kontrol Gruplarının Sontest Toplumsal Cinsiyet Algisı Puanlarına İlişkin Ortalama, Standart Sapma ve Mann Whitney U Testi Sonuçları

\begin{tabular}{|c|c|c|c|c|c|c|}
\hline Grup & Yer & $\mathbf{n}$ & $\bar{X}$ & Ss & $\mathbf{Z}$ & $\mathbf{p}$ \\
\hline \multirow{2}{*}{ ÇKGV } & Deney & 16 & 105,5 & 13,33 & \multirow{2}{*}{4,136} & \multirow{2}{*}{, 000} \\
\cline { 2 - 6 } & Kontrol & 15 & 84,5 & 8,34 & & \\
\hline \multirow{2}{*}{ MBTM } & Deney & 10 & 92,0 & 10,92 & \multirow{2}{*}{1,708} & \multirow{2}{*}{, 088} \\
\cline { 2 - 5 } & Kontrol & 10 & 86,0 & 12,02 & & \\
\hline
\end{tabular}

Tablo 4 incelendiğinde deney ve kontrol grubunun Toplumsal Cinsiyet Alg1sı Ölçeği sontest puanları arasında anlamlı bir farklılık olup olmadığını belirlemek için yapılan Mann Whitney U testi sonuçlarına göre puanlar arasında anlamlı farklılığın olduğu $(\mathrm{p}<, 05)$ görülmektedir. Bu farklılaşma deney grubu lehinedir. $\mathrm{Bu}$ durum yaratıcı drama çalışmasının kadınların toplumsal cinsiyet algılarını geliştirdiğini göstermektedir. 
Uygulama Öncesi ve Sonrası Toplumsal Cinsiyet Algısı Düzeyinin Kendi İçinde Değişimine İlişkin Bulgular

Deney grubunun kendi içinde öntest-sontest ve kontrol grubunun kendi içinde ön test sontest punaları arasında bir fark olup olmadığını belrlemek için Wilcoxon Sıralı İşaretler Testi uygulanmıştır.

Tablo 5: Deney ve Kontrol Grubunun Öntest-Sontest Başarı Puanlarına İlişkin Ortalama, Standart Sapma ve Wilcoxon Stralı Işaretler Testi Sonuçları

\begin{tabular}{|c|c|c|c|c|c|c|c|}
\hline Yer & Grup & $\mathbf{n}$ & Ön test $\bar{X}$ & Son test $\bar{X}$ & Ss & t & p \\
\hline \multirow{2}{*}{ ÇKGV } & Deney & 16 & 93,1 & 105,5 & 13,52 & 4,419 &, 000 \\
\cline { 2 - 8 } & Kontrol & 15 & 84,8 & 84,5 & 11,15 &, 139 &, 892 \\
\hline \multirow{2}{*}{ MBTM } & Deney & 10 & 81,0 & 92,0 & 14,97 & 2,788 &, 021 \\
\hline & Kontrol & 10 & 82,5 & 86,0 & 14,74 &, 858 &, 413 \\
\hline
\end{tabular}

Tablo 5 incelendiğinde Toplumsal Cinsiyet Algısı Ölçeği öntest-sontest puanları arasında anlamlı bir farklılık olup olmadığını belirlemek için yapılan Wilcoxon İşaretli Sıralar Testi sonuçlarına göre;

ÇKGV'da deney grubunun sontest puan ortalamasının $(105,5)$ öntest puan ortalamasından $(93,1)$ anlamlı düzeyde yüksek olduğu görülmektedir $(\mathrm{p}<, 05)$.

MBTM'de deney grubunun sontest puan ortalamasının $(92,0)$ öntest puan ortalamasından $(81,0)$ anlamlı düzeyde yüksek olduğu görülmektedir $(\mathrm{p}<, 05)$.

ÇKGV'da kontrol grubunun sontest puan ortalamasının $(84,5)$ öntest puan ortalamasından $(84,8)$ anlamlı derecede farklı olmadığı görülmektedir ( $\mathrm{p}>, 05)$.

MBTM'de kontrol grubunun sontest puan ortalamasının $(86,0)$ öntest puan ortalamasından $(82,5)$ anlamlı derecede farklı olmadığı görülmektedir ( $\mathrm{p}>, 05)$.

Bu sonuçlar hem ÇKGV'da hemde MBTM'de yapılan deneysel işlemin sontestlerde kadınların toplumsal cinsiyet algısı düzeylerini geliştirdiğini göstermektedir.

\section{İlişkin Bulgular}

Uygulama Öncesi ve Sonrası Toplumsal Cinsiyet Algısı Puanları Arasındaki Farkların Farkına

Deney ve kontrol grubu sontest-öntest puanları arasında farkların farkının anlamlı olmadığını belirlemek amaciyla Mann Whitney U testi yapılmış, sonuçlar Tablo 5'te sunulmuştur.

Tablo 6: Deney ve Kontrol Grubunun Öntest-Sontest Toplumsal Cinsiyet Algısı Puanlarına Ilişskin Ortalama Farkı Standart Sapma ve Mann Whitney U Testi Sonuçları

\begin{tabular}{|c|c|c|c|c|c|c|}
\hline \multirow{2}{*}{ Grup } & Yer & $\mathbf{n}$ & Fark $\bar{X}$ & Ss & Z & p \\
\hline \multirow{2}{*}{ ÇKGV } & Deney & 16 & 12,4 & 6,63 & \multirow{2}{*}{$-3,774$} & \multirow{2}{*}{, 000} \\
\cline { 2 - 6 } & Kontrol & 15 & $-0,3$ & 1,23 & & \\
\hline \multirow{2}{*}{ MBTM } & Deney & 10 & 11 & 8,96 & \multirow{2}{*}{$-2,314$} & \multirow{2}{*}{, 021} \\
\cline { 2 - 5 } & Kontrol & 10 & 3,5 & 11,35 & & \\
\hline
\end{tabular}


Tablo 6 incelendiğinde, deney grubunun ÇKGV'da sontest-öntest puan farkının $(12,4)$ kontrol grubu puan farkından $(-0,3)$ anlamlı düzeyde yüksek olduğu görülmektedir $(\mathrm{p}<, 05)$.

Tablo 5 incelendiğinde, deney grubunun MBTM'de sontest-öntest puan farkının (11) kontrol grubu puan farkından $(3,5)$ anlamlı düzeyde yüksek olduğu görülmektedir $(\mathrm{p}<, 05)$.

Bu sonuçlar hem ÇKGV' da hemde MBTM' de yapılan deneysel işlemin sontest-öntest farkının anlamlı olduğu bununda sontestlerde meydana gelen yükselmeden kaynaklandığını göstermektedir.

\section{Bulgular}

İzleme Çalışması Sonrası Toplumsal Cinsiyet Algısı Düzeyinde Gruplar Arası Değişime İlişkin

Gruplardaki öğrencilerin son testteki başarı düzeyleri arasındaki farklılıkların uygulama sonrası belirlenen süre içerisinde devam edip etmediğini anlamak amacıyla Mann Whitney U testi ile yapılan çözümlemeler tablo 7 'de verilmiştir.

Tablo 7: Deney ve Kontrol Grubunun Sontest-İzleme Testi Toplumsal Cinsiyet Algısı Puanlarına İlişkin Ortalama, Standart Sapma ve Mann Whitney U Testi Sonuçlar

\begin{tabular}{|c|c|c|c|c|c|c|}
\hline Grup & Yer & $\mathbf{n}$ & $\bar{X}$ & Ss & $\mathbf{Z}$ & $\mathbf{p}$ \\
\hline \multirow{2}{*}{ ÇKGV } & Deney & 14 & 105 & 8,15 & \multirow{2}{*}{$-3,774$} & \multirow{2}{*}{, 000} \\
\cline { 2 - 5 } & Kontrol & 13 & 89,8 & 8,81 & & \\
\hline \multirow{2}{*}{ MBTM } & Deney & 10 & 95,2 & 6,08 & \multirow{2}{*}{$-2,314$} & \multirow{2}{*}{, 021} \\
\cline { 2 - 5 } & Kontrol & 10 & 86,4 & 9,52 & & \\
\hline
\end{tabular}

Tablo 7 incelendiğinde deney ve kontrol grubunun Toplumsal Cinsiyet Algısı Ölçeği izleme puanları arasında anlamlı bir farklılık olup olmadığını belirlemek için yapılan Mann Whitney U testi sonuçlarına göre puanlar arasında anlamlı farklılı̆gı olduğu $(\mathrm{p}<, 05)$ görülmektedir. Bu farklılaşma deney grubu lehinedir. $\mathrm{Bu}$ durum yaratıcı drama çalışmasına katılan kadınların yükselen toplumsal cinsiyet algı düzeylerini koruduğunu göstermektedir.

\section{Uygulama Öncesi ve Sonrası ve İzleme Çalışması Sonrası Toplumsal Cinsiyet Algısı Düzeyinin Kendi İçinde Değişimine İlişkin Bulgular}

Deney grubunun kendi içinde öntest-izleme, sontest-izleme ve kontrol grubunun kendi içinde öntestizleme sontest-izleme puanları arasında bir fark olup olmadığını belrlemek için Wilcoxon Sıralı İşaretler Testi uygulanmıştır.

Tablo 8: Deney ve Kontrol Grubunun Öntest-İzleme, Sontest-İzleme Testi Toplumsal Cinsiyet Algisı Puanlarına Ilişkin Ortalama ve Wilcoxon Siralı İşaretler Testi Sonuçları

\begin{tabular}{|c|c|c|c|c|c|c|c|c|c|}
\hline \multirow{2}{*}{ Yer } & \multirow{2}{*}{ Grup } & \multirow{2}{*}{ Sayı } & \multirow{2}{*}{ Ön $\bar{X}$} & \multirow{2}{*}{ Son $\bar{X}$} & \multirow{2}{*}{ İzlem $\bar{X}$} & \multicolumn{2}{|c|}{ Ön $\leftrightarrow$ İzlem } & \multicolumn{2}{|c|}{ Son $\leftrightarrow$ İzlem } \\
\hline \multirow{2}{*}{ ÇKGV } & & & & & & $\mathbf{z}$ & $\mathbf{p}$ & $\mathbf{z}$ & $\mathbf{p}$ \\
\cline { 6 - 10 } & Keney & 14 & 93,1 & 105,5 & 105 & $-2,480$ &, 013 & $-2,357$ &, 163 \\
\hline \multirow{2}{*}{ MBTM } & Dentrol & 13 & 84,8 & 84,5 & 89,8 & $-1,575$ &, 115 & $-1,825$ &, 068 \\
\cline { 2 - 10 } & Kontrol & 10 & 81,0 & 92,0 & 95,2 & $-2,601$ &, 009 & $-1,424$ &, 154 \\
\hline
\end{tabular}


Tablo 8 incelendiğinde Toplumsal Cinsiyet Algısı Ölçeği izleme-öntest, izleme-sontest puanları arasında anlamlı bir farklılık olup olmadığını belirlemek için yapılan Wilcoxon İşaretli Sıralar Testi sonuçlarına göre;

ÇKGV'da deney grubunun izleme puan ortalamasının $(105,5)$ öntest puan ortalamasından $(93,1)$ anlamlı düzeyde yüksek olduğu görülmektedir $(\mathrm{p}<, 05)$.

ÇKGV'da deney grubunun izleme puan ortalamasının $(105,5)$ sontest puan ortalamasından $(105,5)$ anlamlı derecede farklı olmadığı görülmektedir ( $>>, 05)$.

MBTM'de deney grubunun izleme puan ortalamasının $(95,2)$ öntest puan ortalamasından $(81,0)$ anlamlı düzeyde yüksek olduğu görülmektedir $(\mathrm{p}<, 05)$.

MBTM'de deney grubunun izleme puan ortalamasının $(95,2)$ sontest puan ortalamasından $(92,0)$ anlaml derecede farklı olmadığ 1 görülmektedir ( $\mathrm{p}>, 05)$.

ÇKGV'da kontrol grubunun izleme puan ortalamasının $(89,8)$ öntest puan ortalamasından $(84,8)$ anlamlı derecede farklı olmadığ 1 görülmektedir ( $\mathrm{p}>, 05)$.

ÇKGV'da kontrol grubunun izleme puan ortalamasının $(89,8)$ sontest puan ortalamasından $(84,5)$ anlamlı derecede farklı olmadığı görülmektedir ( $\mathrm{p}>, 05)$.

MBTM'de kontrol grubunun izleme puan ortalamasının $(86,4)$ öntest puan ortalamasından $(82,5)$ anlamlı derecede farklı olmadığı görülmektedir ( $\mathrm{p}>, 05)$.

MBTM'de kontrol grubunun izleme puan ortalamasının $(86,4)$ sontest puan ortalamasından $(86,0)$ anlamlı derecede farklı olmadığı görülmektedir ( $\mathrm{p}>, 05)$.

$\mathrm{Bu}$ durum yaratıcı drama çalısmasına katılan kadınların yükselen toplumsal cinsiyet algı düzeylerini önteste göre korudukları, izleme çalışması ile sontestler arasında bir fatklılaşmanın olmadı̆̆ını dolayısıyla kadınalrın toplumsal cinsiyet algı düzeyleri koruduğunu göstermektedir.

Özetle, bu araştırmada toplumsal cinsiyet algısını geliştirme programının kadınların toplumsal cinsiyet algısını geliştirdiği görülmektedir. İzleme çalışması sonrasında bu etki hem ÇKGV'de hem de MBTM'de devam etmektedir.

\section{Uygulanan Programa İlişkin Bulgular}

Yaratıcı drama yöntemiyle yapılan toplumsal cinsiyet algısını geliştirme programını değerlendirmek amacıyla 12 sorudan oluşan "Geri Bildirim Formu" kullanılmıştır. Form katılanlar tarafından son oturumda yazılı olarak yanıtlanmıştır.

\section{“Bir kadın olarak kendinizle ilgili öğrendiğiniz en önemli şey nedir?” Sorusuna İlişkin Bulgular}

$\mathrm{Bu}$ soruya verilen yanıtlardan ortak olanları aşağıda verilmiştir.

- Yaratıcılığımın olduğunu ve grup içerisinde uyumlu olduğumu öğrendim.

- Birliktelik, mutluluk, hoşgörü, huzurlu zaman geçirdik.

- Gruba uyum sağladığımı, fikir üretebildiğimi, grup içerisinde iyi bir dinleyici olduğumu gördüm.

- Seçmeyi, seçilmeyi öğrendim.

- Herkesin fikirlerinin farklı olduğunu öğrendim.

- Eleştiriye açık olmadığımı, eleştirinin dozu kaçınca kırıldım.

- İş hayatımda veya dışarı yaşantımda karşılaşacağım güçlüklerle nasıl başa çıkabileceğimi.

- Yaratıcılığımın olduğunu ve grup içerisinde uyumlu olduğumu öğrendim. 
Genellikle kendine güveninin gelmesi, sevme-sevilme değer verme, istenirse her şeyin başarılabileceği konusunda görüşler belirtilmiştir. Bu değerlendirmeler ışı̆̆ında araştırmanın kadınların kendini değerli görme, güven sağlama gibi konularda olumlu gelişmeler olmuştur.

\section{“Grup yaşantısı içinde ne tür kararlar verdiniz?” Sorusuna İlişkin Bulgular}

$\mathrm{Bu}$ soruya verilen yanıtlardan ortak olanları aşağıda verilmiştir.

- Çok kararım değişti. İstediğim de buydu zaten.

- Çevremde gördüğ̈̈m her insanı olduğu gibi kabul etmem gerektiğine, onlara uyum sağlayıp ortamda kabul görebildiğimi,

- Kendimin de söz hakkı olduğuna,

- Sıkıntıyı atıp yaşamaya bakıyorum,

- Kendi fikirlerimi söyleyip, grup fikrini dinleyip ortak karar vermeyi öğrendim.

- Daha kararlı, 1lımlı, sabırlı olmaya başladım.

Yanıtlar kadınların grup sürecinde yeni kararlar aldıklarnı, bakış açılarının değiştiğini, kişisel gelişim açısından değerlendirildiğinde, özellikle kendi fikirlerini ortaya koymak, stresten uzak kalmak, umutsuzluğa kapılmamak gibi kişisel olarak güçlenme konusunda olumlu adımlar atılmıştır.

\section{İlişkin Bulgular}

“Bu gruptan alıp günlük yaşamınızda en çok uygulamak istediğiniz şey ne olabilir?” Sorusuna

$\mathrm{Bu}$ soruya verilen yanıtlardan ortak olanları aşağıda verilmiştir.

- Sevgi, saygı, hoşgörü, , huzur, anlayışı, güler yüzlü ve neşeli.

- İçinden gelen her şeyi söyleyebilmek.

- Kendimin bir şeyleri başarabilmesi.

- Biraz daha sabırlı olmak.

- Her şeye rağmen eleştirmek.

- Yaratıcılığı yaşamıma aktarmak.

Yanıtlar kadınların kendi hayatlarında daha insana özgü sevgi, saygı, hoşgörü çerçevesinde yaşamak yönündedir. Kadınlar çevresiyle daha paylaşımcı ve olumlu ilişkiler sağlamak istemektedirler.

\section{“Grupta başka neleri tartışmak isterdiniz?” Sorusuna İlişkin Bulgular}

$\mathrm{Bu}$ soruya verilen yanıtlardan ortak olanları aşağıda verilmiştir.

- Genellikle her şeyi tartıştık.

- Maddi durumumuzu.

- Çocuk eğitimini.

- Herkesin birbirine destek olmasinı.

- Güncelliği yaşadığımız sorunları.

- Doğruyu bulmak için yanlışların üstüne daha gitmek isterdim. 


\section{“Grupta sizin görüşlerinizle çelişen görüşler olduğunda neler hissettiniz?” Sorusuna İlişkin} Bulgular

Bu soruya verilen yanıtlardan ortak olanları aşağıda verilmiştir.

- Sayg1 gösterdim.

- Genellikle herkesin düşüncesi farklı.

- Hiç olmadı, çok güzeldi.

- Kendime ve arkadaşlarıma güven hissederim.

- Bunun doğru bir iş olduğunu.

- Daha iyi oldu.

- Grubun benim görüşlerime saygılı olduğunu hissettim.

- Evde düşünüp, doğruyu buldum.

- Farklı görüşlere sahip grup üyelerini dinleyip acaba hangimiz doğru düşünüyor mantığını araştırıp, dinleme ile olumsuz duygulara kapılmadım.

Genellikle saygı gösterdim gibi ifadeler kullanılmıştır.

“Grupta yaratılan ortam gerçek yaşamdan kopuktur. Ne dersiniz?” Sorusuna İlişkin Bulgular

$\mathrm{Bu}$ soruya verilen yanıtlardan ortak olanları aşağıda verilmiştir.

- Bazen

- En doğal halimizle davrandık.

- Herkes geçmişe dönüyor.

- Yaratılan grup ortamı oldukça doğal olup her üye hayatı hakkında paylaşımlarda bulundu.

- Değildi, aksine yaşamdan çok şey vardı.

Görüşler genellikle yaratılan ortamın yaşamla bir bağ içersinde olduğu yönündedir.

“Programa eklenmesi, geliştirilmesi veya çıkarılması gereken konular var mı?” Sorusuna İlişkin

\section{Bulgular}

$\mathrm{Bu}$ soruya verilen yanıtlardan ortak olanları aşağıda verilmiştir.

- Yok

- Kendimizi geliştirecek daha değişik programlar ve konular olmalıdır

- Tiyatroyla sonuçlanmasını isterdim.

- Birazda etiği eleştirici olmalı.

"Bu çalışmada en çok ilginizi çeken konu ve etkinlikler nelerdi?" Sorusuna İlişkin Bulgular

$\mathrm{Bu}$ soruya verilen yanıtlardan ortak olanları aşağıda verilmiştir.

- Kadınlar hakkındaki tartışmalar. Çektiği sıkıntılar.

- Gülmek, stres atmak.

- Şiddete karşı konuşmalar. 
- Yaratıcı dramaları düşünüp başarılı olmak.

- Genç, yaşlı demeden hepimiz eşit olduk.

- Çocuk oyunları oynamak, doğaçlama yapmak.

- Yatıcı drama. Hiç tiyatro eğitimi olmayan kadının oynaması.

- Yaşanan olayları oyunlarla da olsa hayata geçirmek.

- Kadının ev ve iş hayatında nasıl olduğunu grup içinde yapılan etkinlikler. ile göstermesi ilgimi çekti. $\mathrm{Bu}$ sayede kadınlar hakkında bilgim artt1.

- Toplumsal sorunları o anda yarattığımız oyunlarla işlememiz.

\section{“Benim için bu çalışmaların en olumsuz ve zayıf yanı” Sorusuna İlişkin Bulgular}

$\mathrm{Bu}$ soruya verilen yanıtlardan ortak olanları aşağıda verilmiştir.

- Hiç olumsuz yanı yok.

- Arkadaşların zamanında gelmemesi.

- Zamanın kisa olması.

- İlk başta hocamızın erkek olması. Ama sonra çok iyi oldu.

- Grup üyelerinin katılıma çok özen göstermemesi.

- Çok sık hoplayıp zıpladık, yorulduk.

- Malzeme eksikliğii.

- Birbirini dinlememe.

Genellikle olumsuz yanının olmadığına ilişkin yorumlar olsa da, en çok katılıma özen göstermeme konusunda olumsuz geri bildirimler verilmiştir.

"Benim için bu çalışmaların en olumlu ve üstün yanı” Sorusuna İlişkin Bulgular

$\mathrm{Bu}$ soruya verilen yanıtlardan ortak olanları aşağıda verilmiştir.

- Kendime güvenim geldi. Mutlu oldum.

- Bilmediklerimizi öğrenmek.

- Kendimizi ifade etmek, yaşayamadığımız çocukluğu yaşamak.

- Gam kederi bir yana bırakıp, her şeye pozitif görmek.

- Kendimi ifade etmemi ve kendi düşüncelerimden drama yaratmak.

- Kadınların kaynaşması, birbirine saygı duyması.

- Az zamanda iyi bir şey olması.

Alınan geri bildirimler doğrultusunda, kadınların, özellikle kendine güven, kendini ifade etme, yeni bilgi öğrenme gibi konularda bir gelişim gösterdikleri söylenebilir. 


\section{"Liderin nitelikleri hakkında neler düşünüyorsunuz?" (Lider ve liderin tutumunun grup üzerindeki etkisi) Sorusuna İlişkin Bulgular}

$\mathrm{Bu}$ soruya verilen yanıtlardan ortak olanları aşağıda verilmiştir.

- Hoca gerçekten çok iyi biri. İyi ki tanımışız. Benim için çok iyi oldu.

- Kadınların ruhundan anlıyor.

- Çok sevdik. Çok iyi bir insan. Etkisi çok oldu.

- Çok cana yakın.

- Bize çok güzel şeyler öğretti. Sevmeyi saygıyı öğretti. Tartışmayı ve her zaman doğruyu öğretti.

- $\quad$ Çok iyi ve becerikliydi, sabırlıydı ve sevecendi.

- Öncü, koruyucu, sevecen ve işi öğreten. İşini sağlığından üstün tutan.

- Gayet başarıl1.

- Konuya hakim olması ve pes etmemesi.

- C Çok güzel bir faaliyet. Hüseyin bey zaten mükemmel içimizden biri gibi. Böyle olması daha güzel. İyi ki katılmışım. Kendimi çok şanslı görüyorum.

- Grupta hocamı tanımaktan son derece memnun oldum. Bu derslerin yeni dönemde de devam etmesini temenni ederim.

- Hocamızı çok sevdiğimizi bilmesini istiyoruz.

- Çok hocayla çalıştık ama bu kadar kararlı olanı görmedik. Bunu her zaman yapmasını istiyoruz. Hayat boyu devam etmesini istiyoruz.

Kadınlar liderin erkek olmasına rağmen iyi ilişkiler geliştirmişler, kendilerini kolaylıkla ifade edebilmişlerdir.

\section{“Diğer duygu ve düşünceleriniz nelerdir?” Sorusuna İlişkin Bulgular}

$\mathrm{Bu}$ soruya verilen yanıtlardan ortak olanları aşağıda verilmiştir.

- Yeni arkadaşlar tanıdık. Mutlu olduk. Haklarımızı öğrendik.

- Her şey çok güzeldi. Buraya katıldığım için çok mutlu oldum.

- Keşke bitmeseydi.

- Kendime güvenim geldi.

- Bana güven duymalar1.

- Beni 2-3 saat sorunlarımdan uzaklaştırdığı, çocuk gibi eğlenmemi özgürce oynadık.

- Çok mutluydum. Bilmediklerimi öğrendim.

- Bana çocuklukta yapamadıklarımı yapma firsatı verdi. Devamını dilerim.

- Benim evden çıkıp 2-3 saatte olsa bütün kötü şeylerden uzaklaştırıp oradaki ortama uygun zaman geçirdim.

- Böyle bir çalışma içersinde bulunduğumdan dolayı mutluyum. 
- $\quad$ Bu drama dersine katılmaktan dolayı son derece mutluyum. Kendimi böyle bir çalışmanın içerisinde bu ortamda bulmaktan büyük keyif aldım.

- Bu eğitici programın tekrarını istiyoruz. Hocamız çok sabırlı sevimli ve hâkim olması bizi çok etkiledi. Olaya çok hâkim ve başarılı.

- Değişik grupla daha uzun zamanlı çalışma sonunda bunu bir oyunla sergilemek.

\section{Sonuç ve Tartışma}

Araştırma sonucunda elde edilen sonuçlar şu şekildedir;

Grup oturumları başlamadan önce kadınların toplumsal cinsiyet algısı orta seviyededir. Kadınlar toplumsal cinsiyet rolü bakımından eğitime ve bilgilendirmeye ihtiyaç duymaktadırlar.

Grup oturumları başlamadan önce kadınların toplumsal cinsiye algısı bakımından grup çalışmasına katılan ve katılmayanlar arasında anlamlı bir fark bulunmamaktadır.

Grup oturumları sonrasında kadınların toplumsal cinsiyet algısı bakımından grup çalışmasına katılan ve katılmayanlar arasında anlamlı bir fark bulunmuştur. Bu fark oturumlara katılanlar lehinedir.

Grup çalışmasından sonra deney grubundaki kadınların cinsiyet rolü algısı düzeylerinde grup çalışması öncesine oranla anlamlı düzeyde artışın olduğu anlaşılmaktadır. Kontrol grubunda bu düzey aynı seviyede kalmıştır.

İzleme çalışmasından sonra deney grubundaki kadınların cinsiyet rolü algısı düzeyindeki artışın devam ettiği anlaşılmaktadır. Kontrol grubunda bu düzey aynı seviyede kalmıştır.

Program sonunda kadınların kazanımları aşağıdaki gibi özetlenebilir:

Kadının toplumsal cinsiyet kavramları konusunda bilinçlenmesi,

Kadın erkek ayırımcılığı konusunda bilinçlenme,

Başta ifade özgürlüğü, eğitim ve çalışma hakları olmak üzere kadının insan haklarının daha fazla ve etkin kullanım isteğinin artması,

Kadınların, çocukların eşitlikçi, kalıp yargılarda uzak yetiştirme konusunda bilinçlenme,

Kendi yaşam koşullarını irdelemeye başlama,

Fiziksel, duygusal ve ekonomik şiddet hakkında bilgi sahibi olma ve yenme konusunda bilinçlenme,

Toplumsal alana çıkma ve sorumluluk üstlenmedir.

Kadınların haklarını bilmeleri, hakları için mücadele etmeleri için güçlenmeleri gerekir. Bu bağlamda Sayılan (1993), feminist bir yaklaşımla yaptığı araştırmasında grup sürecinin kadınların güçlenmesinde önemli katkı sağladığı sonucuna erişmiştir.

Sonuç olarak kadın cinsiyetine sahip olmak pek çok problemi beraberinde getirmektedir. Geleneksel cinsiyet rolleri, kadınlar için olumsuz sonuçlar yaratmaktadır. Bu olumsuz sonuçlar, insanların kendilerini gerçekleştirmelerine, mutlu olmalarına engel olmaktadır. Mutlu, anlamlı, bir yaşam için insanların kendilerini istedikleri gibi biçimlendirmelerine izin verilmelidir. Bunun için de özellikle kadınların psikolojik, ekonomik, siyasal ve eğitim açısından güçlendirilmeleri gerekmektedir. Kadınların statüsünü yükseltmek için sürdürülen mücadelelerde kadın haklarını savunmak, daha iyi bir hayat için insan haklarının siyasal, sosyal, hukuksal ve ekonomik boyutunda eşitlik arayışını dile getirmek gerekir. Kadının aktif bir konuma sahip olarak toplumsal 
yaşamın her alanında yerini alabilmesi, hem kadınların kendine bakışını değiştirmesi hem de doğumla başlayan toplumsal cinsiyeti şekillendiren toplumsal rol kalıplarının ve tutumlarının değişmesiyle olasıdır. Bu da ancak haklarının bilincinde ve bunları kullanmaya hazır “güçlü” kadınların varlığı ile gerçekleştirilebilir.

\section{Öneriler}

Aşağıda elde edilen bulgulardan yola çıkarak ileride yapılacak çalışmalara 1şık tutabilecek ve alanda çalışan kişilere yardımcı olabilecek önerilere yer verilmiştir.

Kadınlara yapılacak güçlendirme çalışmalarının daha etkili olabilmesi için uzun süreli çalışmaların yapılmasının önemli olduğu düşünülmektedir.

Eğitim programının uygulandığı grubun sayısı, araştırmalarda ve yaratıcı drama çalışmalarında önem taşımaktadır. Yaratıcı drama çalışmalarının daha sağlıklı bir şekilde sürdürülebilmesi, grup içindeki etkileşimin daha fazla olabilmesi ve gruptan ayrılmalar nedeniyle yaşanan olumsuzluklardan daha az etkilenilmesi amacıyla üye sayısına ve devam durumlarına özen gösterilmelidir.

Toplum merkezlerinde yaratıcı drama çalışmalarına daha çok yer verilmelidir. Yaratıcı drama yöntemiyle eğitimlere daha çok kadının katılabileceği, toplum merkezlerinde çalışan meslek elemanları tarafından da göz önünde tutulmalıdır.

Benzer çalışmalar ilköğretim, lise, üniversite, çalışan kadınlar ve farklı sosyoekonomik seviyedeki tüm kadınlar üzerinde yapılabilir.

Toplumsal cinsiyet bilinci geliştirmeye yönelik eğitimler yalnızca kadınlara değil erkeklere yönelik olarak hazılanmalı ve verilmelidir. 


\section{Kaynakça}

Alkan A. (2005). Yerel yönetimler ve cinsiyet kadınların kentte görünmez varlı̆̆ı. Ankara: Dipnot Yayınları.

Altınova, H.H. ve Duyan, V. (2013). Toplumsal cinsiyet algısı ölçeğinin geçerlik güvenirlik çalışması. Toplum ve Sosyal Hizmet, 24, (2), 9-22

Atauz, A. Kardam, F. Saktanber, A. vd. (1999). Toplumsal cinsiyet eğitimi el kitabl. Ankara: Yayınlanmamış eğitim materyali, KSSGM.

Bhasin, K. (2003). Toplumsal cinsiyet "bize yüklenen roller”. (K. Ay, Çev.). İstanbul: Kadın Dayanışma Vakfı Yayınları.

Bora, A (2012). Toplumsal cinsiyete dayalı ayrımcılık. Ayrımcılık: Çok Boyutlu Yaklaşımlar. (Der: Kenan Çayır ve Müge Ayan Ceyhan) İstanbul bilgi üniversitesi yayınları

Bora, A. (2010). Kadınların sınıfi. İletişim Yayınları, İstanbul

Büyüköztürk, Ş. (2001). Deneysel desenler. Ankara: Pegem A, Yayıncılık.

Connell, R.W. (2003). The role of men and boys in achieving gender equality. 29.07.2012, http://www.un.org/womenwatch/ daw/egm/menboys2003/Connell-bp.pdf.

Çamur, G. (2002). Kentleşme sürecinde gecekondulaşma ve toplum merkezleri. Sosyal Hizmet Sempozyumu 1998 (Antalya) Bildirileri, Kentleşme Sürecinde Sosyal Hizmet, H.Ü Sosyal Hizmetler Yüksekokulu Yayını, 45-50

Fichter, J. (1994). Sosyoloji nedir. Çeviren: N. Çelebi. Ankara: Atilla Kitabevi.

Günay, G. ve Bener, Ö. (2011). Aile içi yaşamı algılama biçimleri. TSA/Yı1: 15 S: Aralık

Karasar, N. (2000). Bilimsel araştırma yöntemi-kavramlar, ilkeler, teknikler. 10.Bask1. Nobel Yayınevi. Ankara.

Mackie, D. M., Hamilton, D. L., Susskind, J. ve Rosselli, F. (1996). Social psychological foundations of stereotype formation. (Derleyenler: C. N. Macrae, C. Stangor ve M. Hewstone), Stereolype And Stereotyping Ny: Guilford, 41-47

Moya, M. Expósito, F. ve Ruiz, J. (2000). Close relationships, gender, and career salience. Sex Roles 42,9-10,825-846.

Poole, R. (1993). Ahlak ve modernlik. (M. Küçük, Çev.). İstanbul: Ayrıntı Yayınları.

Powell , G.N. ve Greenhaus, J.H. (2010). Sex, Gender, and Decisions at The Family - Work Interface. Journal of Management. 36 (4),1011-1039.

Sakallı-Uğurlu,N. (2003). Cinsiyetçilik: kadınlara ve erkeklere ilişkin tutumlar ve çelişik duygulu cinsiyetçilik kuramı. Türk Psikoloji Yazılarl, 6 (11-12), 1-20

Savran, G. A. (2008). Kadının görünmeyen emeği.(10-16). İkinci Basıma Önsöz içinde G. Savran ve N. Tura Demiryontan, İstanbul: Yordam Kitap.

Sayılan, F. (1993). Kadın eğitimine feminist bir yaklaşım çankaya belediyesi 100. yll kültür evinde uygulamalı bir araştırma. Yayımlanmamış Yüksek Lisans Tezi. Ankara Üniversitesi Sosyal Bilimler Enstitüsü, Ankara.

Scott, J. W. (2007). Toplumsal cinsiyet: faydalı bir tarihsel analiz kategorisi. (A. T. Kılıç, Çev.). İstanbul: Agora Kitaplığı.

Stromquist, N.P. (2002). Education as a means for empowering women, rethinking emporerment: gender and development in a global/local world. (Ed. Jane L. Parpart, Shirin M. Rai, Katleen Staudt. Çev: Fevziye Sayılan), London: Routledge.

Tanrı̈̈ver, H. (2003). Türkiye'de televizyon kültürü ve kadınlar. kadın yaşantıları. (Yayına Haz. Ayşegül Yaraman) İstanbul: Bağlam Yayınları.

Terzioğlu, F. ve Taşkın, L. (2008). Kadının toplumsal cinsiyet rolünün liderlik davranışlarına ve hemşirelik mesleğine yansımaları. C.Ü. Hemşirelik Yüksekokulu Dergisi. 12,(2),62-67.

Timisi, N. (1997). Medyada cinsiyetçilik. Ankara: KSSGM Yayını.

Yaşın Dökmen, Z. (2004). Toplumsal cinsiyet: sosyal psikolojik açıklamalar. İstanbul: Sistem Yayıncılık.

Yılmaz, R. Ayhan (2007). Reklamlarda toplumsal cinsiyet kavramı: 1960-1990 yılları arası milliyet gazetesi reklamlarına yönelik bir içerik analiz. Selçuk Üniversitesi İletişim Fakültesi Akademik Dergisi, 143-155.

Yogev, S.P. (2006). Ergenlerde toplumsal cinsiyetin kazanılması aile, okul ve arkadaş etkisi. Yayımlanmamış Yüksek Lisans Tezi. Ankara Üniversitesi Sosyal Bilimler Enstitüsü, Ankara 